\title{
Finansuj lub giń. Ludzie nauki, prestiżowe publikacje a system finansowania $B+R$ w Polsce ${ }^{3}$
}

\begin{abstract}
The aim of this article is to present the possible relationship between the level of financing of $\mathrm{R}+\mathrm{D}$, the $\mathrm{R}+\mathrm{D}$ personnel rate (particularly in the higher education sector) and the presence of Polish academic research in the world demonstrated by prestigious publications indexed in the Web of Science (WoS). The research findings concern the analysis of changes in time and show a clear, strong and positive correlation between the level of financing of research and development activity and the number of publications listed in the WoS. The received result indicates with a well-fitting regression model that there is a direct relationship between the expenditure on research and the presence of Polish scholars in the international science.
\end{abstract}

\section{Key words:}

Polish academic research, higher education, science policy, research evaluation, Web of Science, $\mathrm{R}+\mathrm{D}$, publishing policy

1 Agnieszka Jeran, Instytut Socjologii, Wydział Nauk Społecznych, Uniwersytet im. Adama Mickiewicza w Poznaniu, Polska, jeran@amu.edu.pl.

2 Joanna Piechowiak-Lamparska, Wydział Politologii i Studiów Międzynarodowych, Uniwersytet Mikołaja Kopernika w Toruniu, Polska, jpiechowiak@umk.pl.

3 Badania zrealizowano w ramach projektu „System nauki w Polsce - uwarunkowania instytucjonalne”, grant nr BN/SPOL/12/2015, Fundacja Copernicus na rzecz Wspierania Badań Naukowych. 


\section{ILE KOSZTUJE NAUKA? PRÓBA ODPOWIEDZI NA PYTANIE RETORYCZNE}

Pytanie o to, ile kosztuje nauka, jest w rzeczywistości pytaniem o cenę rozwoju społeczno-gospodarczego i nie wydaje się możliwe udzielenie na nie prostej odpowiedzi. Można jednak spróbować udzielić odpowiedzi na pytanie, ile kosztuje dobra uczelnia wyższa i co ma w zamian do zaoferowania. Powinna z pewnością oferować dobrze wykształconych absolwentów oraz wyniki badań, które mają wpływ na rozwój społeczeństwa i państwa. Można także spróbować sprawdzić, ile środków przeznaczanych jest na finansowanie całego sektora szkolnictwa wyższego, a także - ile przeznacza się w państwie środków na prowadzenie badań naukowych i jak te nakłady przekładają się na efekty. Obecnie kwestia finansowania nauki jest jednym z najważniejszych obszarów badawczych z zakresu badań nad szkolnictwem wyższym (zob. Brada, Bienkowski, Kuboniwa, 2015; Keszei, Hausz, Fonyó, Kardon, 2015; Tilak, 2015; Kaiser, Maassen, Meek, van Vught, de Weert, Goedegebuure, 2014; Phillips, Olson, 2015; Wilkin, 2009; Kwiek, 2016). Istotnym problemem jest zatem analiza korelacji pomiędzy finansowaniem nauki a możliwymi do zaobserwowania zależnościami z liczbą ludzi nauki oraz popularyzacją wyników badań. Celem tego artykułu jest zbadanie i ukazanie możliwego związku pomiędzy poziomem finansowania $\mathrm{B}+\mathrm{R}$ i poziomem zatrudnienia w instytucjach naukowo-badawczych a obecnością polskiej nauki na świecie przejawiającą się publikacjami uchodzącymi za najbardziej prestiżowe, czyli indeksowanymi w Web of Science (WoS) ${ }^{4}$.

Nauka pod względem finansowym wydaje się być workiem bez dna, który jest w stanie wchłonąć dowolnej wielkości środki. Jerzy Wilkin (2010, s. 138) zwraca uwagę, że „dobry uniwersytet jest zazwyczaj bardzo drogim uniwersytetem”. Także Ryszard Borowicz (2000) stwierdza, że „trudno wyobrazić sobie również funkcjonowanie szkolnictwa wyższego szczebla bez znaczących wzmocnień finansowych”. Uniwersytety uplasowane na pierwszych miejscach światowych rankingów uczelni wyższych dysponują ogromnymi budżetami oraz imponującym majątkiem trwałym. Dobra uczelnia wyższa to taka, która - np. według Listy

4 Web of Science jest najwyżej ocenianą przez Ministerstwo Nauki i Szkolnictwa Wyższego w Polsce bazą czasopism (za publikacje w czasopismach tam indeksowanych można otrzymać od 15 do 50 punktów - Lista A, natomiast za publikacje w innych czasopismach, w tym umieszczonych na The European Reference Index for the Humanities, można otrzymać od 10 do 25 punktów - Lista C; na Liście B czasopisma mogą otrzymać do 15 punktów) (zob. Jeran, Piechowiak-Lamparska, 2015; Rozporządzenie Ministra Nauki i Szkolnictwa Wyższego z dnia 12 grudnia 2016 r. w sprawie przyznawania kategorii naukowej jednostkom naukowym i uczelniom, w których zgodnie z ich statutami nie wyodrębniono podstawowych jednostek organizacyjnych). 
Szanghajskiej - reprezentuje wysoki poziom w kilku najważniejszych obszarach: jakości edukacji (quality of education), jakości wydziałów/jednostek naukowych (quality of faculty), wyników badań (research output) oraz wydajności (per capita performance) (zob. Academic Ranking of World Universities methodology). Nietrudno sobie wyobrazić, że wszystkie te czynniki są w istotnym stopniu zależne od budżetu. Jakość edukacji wyznaczana jest według metodologii tego rankingu przez liczbę absolwentów nagrodzonych Nagrodą Nobla. Jak zatem można skusić najlepszych studentów? Konieczne jest zapewnienie im możliwie doskonałych warunków rozwoju: najlepszych nauczycieli akademickich oraz najlepszych warunków odbywania zajęć i prowadzenia badań, ale także najlepszych warunków studiowania. Jakość wydziałów/jednostek naukowych wyznaczana jest przez liczbę pracowników nagrodzonych Nagrodą Nobla lub medalem Fieldsa, a także wskaźnikiem cytowalności publikacji. Najlepsi nauczyciele akademiccy pracują tam, gdzie mają zapewnione najlepsze warunki do prowadzenia badań (chociażby poprzez możliwość tworzenia zespołów badawczych lub zakup czy budowę najnowocześniejszej aparatury) oraz odpowiednio wysokie wynagrodzenia. Najlepsze i najczęściej cytowane publikacje są pisane przez najlepszych naukowców. Jest to oczywiście truizm, jednak pozwala dostrzec intuicyjnie oczywisty związek przyczynowo-skutkowy pomiędzy dobrą uczelnią wyższą a poziomem finansowania.

Oczywiście, w polskich warunkach przywołane powyżej wskaźniki muszą ulec znaczącemu okrojeniu, z dosyć oczywistych względów liczba laureatów Nagrody Nobla słabo różnicuje polskie uczelnie i w konsekwencji niewiele mówi. Truizmem jest także wskazywanie na fakt, że postulowane powyżej związki znakomicie ogranicza niewielka mobilność polskich naukowców, zarówno w wymiarze krajowym, jak i międzynarodowym. Jedynie mobilność mogłaby zagwarantować stopniowe grupowanie się najlepszych ludzi nauki. Sztywne warunki finansowania związane z przyznawaniem dotacji ze środków budżetowych i równie sztywne ramy wynagradzania sprawiają, że tylko bezpośrednie pozyskanie środków grantowych może być czynnikiem różnicującym. Jakie pozostają do przeanalizowania związki w warunkach takiego skrępowania adekwatności analiz czynnikami ludzkimi i finansowymi? Oczywiście, nieodmiennie istotna jest kwestia możliwych do rozdysponowania środków, zaś spośród przywołanych wskaźników wpływu oraz widoczności w światowym dyskursie najbardziej przystawalnym wydaje się cytowalność. Możliwe do przeanalizowania bazy danych zmuszają jednak do dalszego ograniczenia analizy do podstawowego czynnika, jaki stanowi sama obecność prestiżowych publikacji polskich autorów w światowym obiegu nauki. Pozwala to na próbę udzielenia odpowiedzi na pytanie, czy zachodzi omawiana korelacja. Z tego też względu w przeprowadzonych analizach podjęto trop związków po- 
między wydatkami na naukę, liczbą pracowników nauki (i ich zaangażowaniem w działalność naukowo-badawczą) oraz obecnością prac polskich autorów (jako autorów tekstów wykazujących się afiliacją w polskiej instytucji) w uchodzącej za najważniejszą na świecie bazie indeksującej czasopisma naukowe, tj. bazie Web of Science, opartej na liście czasopism JCR.

\section{DANE I METODA ANALIZY}

W procesie analizy wykorzystywano dane pochodzące przede wszystkim z zestawień GUS, dlatego szczególnie istotne są definicje przyjmowane przez GUS przy ich gromadzeniu. Zgodnie z nimi:

- nauczyciele akademiccy w szkole wyższej to „pracownicy zatrudnieni na stanowiskach: profesora zwyczajnego, profesora nadzwyczajnego, profesora wizytującego, docenta, adiunkta, asystenta, wykładowcy, starszego wykładowcy, lektora, instruktora” (GUS, 2015a, s. 11). Ważna uwaga dotyczy zliczania tej samej osoby wielokrotnie, jeśli jest zatrudniona w więcej niż jednej szkole wyższego, co wynika z możliwej (choć coraz rzadszej) wieloetatowości. W efekcie liczba osób wykazywanych jako nauczyciele akademiccy jest wyższa od liczby osób zajmujących się nauczaniem w szkołach wyższych oraz prowadzeniem w nich badań naukowych;

- środki finansowe związane z działalnością naukową klasyfikowane są jako „przychody ogółem z działalności badawczej”, co obejmuje przede wszystkim „dotacje na finansowanie działalności statutowej (...), środki na realizację projektów finansowanych przez Narodowe Centrum Badań i Rozwoju oraz Narodowe Centrum Nauki, środki na finansowanie współpracy naukowej z zagranicą, sprzedaż pozostałych prac i usług badawczych i rozwojowych” (GUS, 2015a, s. 13). Z perspektywy wydatkowania środków na działania badawcze w szkołach wyższych jest to główna kategoria zapewniająca środki na te badania (choć mogą one pochodzić także z innych źródeł);

- działalność badawczo-rozwojowa (B+R) obejmuje: badania podstawowe, badania stosowane i prace rozwojowe. $\mathrm{Z}$ kolei personel B+R to „wszystkie osoby związane bezpośrednio z działalnością $\mathrm{B}+\mathrm{R}$, zarówno pracownicy merytoryczni, jak i personel pomocniczy. Do pracowników związanych bezpośrednio z działalnością B+R zaliczani są pracownicy przeznaczający na tę działalność co najmniej 10\% swojego ogólnego czasu pracy” (GUS, 2015b, s. 19). Podstawowym przelicznikiem zapewniającym porównywal- 
ność w zakresie zaangażowania zasobów ludzkich w B+R jest ekwiwalent pełnego czasu pracy (EPC) - są to ,jednostki przeliczeniowe służące do ustalania faktycznego zatrudnienia w działalności B+R. Jeden EPC oznacza jeden osoborok poświęcony wyłącznie na działalność B+R” (GUS, 2015b, s. 20). Zatrudnienie $\mathrm{w}$ działalności $\mathrm{B}+\mathrm{R}$ jest ustalane poprzez proporcję czasu przepracowanego przy pracach $\mathrm{B}+\mathrm{R}$ w stosunku do pełnego czasu pracy obowiązującego w danej instytucji na określonym stanowisku pracy. Jeśli zatem pracownik połowę swojego czasu pracy przeznacza na działalność B+R, to przeliczane jest to na 0,5 EPC.

Obok danych GUS w analizach wykorzystano dane zgromadzone przy przeszukiwaniu zasobów bazy Web of Science (polegające na wyszukaniu wszystkich publikacji w zbiorze Web of Science, w których chociaż jeden z autorów afiliowany był na polskiej uczelni lub jednostce naukowo-badawczej) ${ }^{5}$.

Z wykorzystaniem danych pozyskanych z baz GUS oraz własnych analiz bibliometrycznych przeprowadzono analizy trendu oraz analizy o charakterze korelacyjnym obejmujące okres od 2006 do 2014 roku. Celem tych analiz było wskazanie trendów w trzech analizowanych obszarach:

- zatrudnienia pracowników bezpośrednio związanych z działalnością B+R wraz ze wskaźnikami stopnia zaangażowania w tę działalność;

- wydatków Polski na działalność B+R;

- obecności polskich publikacji w bazie indeksującej WoS, a więc w objętym nią światowym obiegu wiedzy naukowej.

W zakresie analizy korelacyjnej postawiony cel badawczy obejmował rozpoznanie kierunku i charakteru korelacji pomiędzy trendami w wymienionych obszarach.

\section{WYNIKI}

W zakresie analizy trendów zatrudnienia pracowników związanych z działalnością B+R w analizowanym okresie (2006-2014) zostały ustalone następujące kwestie:

- liczba nauczycieli akademickich w Polsce nieznacznie zmalała;

- liczba pracowników B+R w sektorze szkolnictwa wyższego wzrosła (zarówno przy uwzględnieniu liczby osób, jak i EPC);

5 Dane zostały zebrane w dniach 8-28.05.2016. 
- zaangażowanie pracowników sektora szkolnictwa wyższego w działalność B+R było połowiczne, choć rosnące. Należy przy tym zauważyć, że zaangażowanie to (jako wskaźnik intensywności zaangażowania) jest szacowane na podstawie proporcji liczby pracowników $\mathrm{B}+\mathrm{R}$ w sektorze i odpowiadającej im liczby EPC. „Połowiczność” oznacza tu, że określona liczba pracowników przekłada się na około połowę mniejszą liczbę EPC dla porównania, w sektorze przedsiębiorstw czy rządowym tak wyznaczony stopień zaangażowania osiągał w 2014 roku wartość 80\%.

Tabela 1. Zatrudnienie i zaangażowanie w działalność $B+R$ w sektorze szkolnictwa wyższego w latach 2006-2014

\begin{tabular}{|c|c|c|c|c|c|c|c|c|c|}
\hline wyszczególnienie & 2006 & 2007 & 2008 & 2009 & 2010 & 2011 & 2012 & 2013 & 2014 \\
\hline $\begin{array}{l}\text { nauczyciele akade- } \\
\text { miccy } \\
\text { [pełne etaty] }\end{array}$ & 98262 & 99221 & 100137 & 101561 & 101627 & 100808 & 100738 & 98497 & 96534 \\
\hline $\begin{array}{l}\text { zatrudnieni w B+R } \\
\text { w sektorze szkolnic- } \\
\text { twa wyższego } \\
\text { [w osobach] }\end{array}$ & 80162 & 80187 & 79523 & 79261 & 80918 & 80719 & 80130 & 80223 & 82463 \\
\hline $\begin{array}{l}\text { zatrudnieni w B+R } \\
\text { w sektorze szkol- } \\
\text { nictwa wyższego } \\
\text { [EPC] }\end{array}$ & 415351 & 42595 & 43485 & 41440 & 43111 & 44154 & 42917 & 41441 & 44304 \\
\hline $\begin{array}{l}\text { wskaźnik intensyw- } \\
\text { ności zaangażowa- } \\
\text { nia pracowników } \\
\text { B+R } \\
\text { w działalność B+R } \\
\text { [w \%] }\end{array}$ & 51,8 & 53,1 & 54,7 & 52,3 & 53,3 & 54,7 & 53,6 & 51,7 & 53,7 \\
\hline
\end{tabular}

Źródło: Obliczenia własne na podstawie danych GUS.

Przywołane wyniki wyraźnie wskazują, że nawet aktywni w zakresie B+R pracownicy szkół wyższych na tę działalność przeznaczają przeciętnie około połowy swojego czasu pracy (w przypadku porównania ogólnej liczby nauczycieli akademickich i EPC w działalności badawczo-rozwojowej wskaźnik jest jeszcze niższy i w roku 2014 wynosił 46\%). Nie jest to w istocie wynik zaskakujący obowiązki nauczyciela akademickiego to nie tylko działalność naukowa, ale w ogromnej mierze dydaktyczna, a także organizacyjno-administracyjna.

Drugi obszar analizy dotyczy trendów w zakresie finansowania działalność badawczej. Podstawowym wskaźnikiem opisującym wielkość tych nakładów i pozwalającym na prowadzenie porównań międzyokresowych oraz międzynaro- 
dowych jest wartość nakładów na $\mathrm{B}+\mathrm{R}$ wyrażona jako udział w $\mathrm{PKB}$. W Polsce od 2014 roku można obserwować stopniowy wzrost udziału nakładów na B+R, od poziomu 0,56\% PKB do 0,94\% PKB. Chociaż kierunek ten jest w pełni zgodny chociażby ze strategiami rozwojowymi Polski i UE, to jednak osiągnięty poziom nadal jest odległy od celu wyznaczonego jako 3\% PKB wydatkowanego na działalność badawczo-rozwojową. Jednocześnie środki, jakimi z przeznaczeniem na działalność badawczą dysponowały szkoły wyższe, wzrosły w analizowanym okresie niemal trzykrotnie. Należy przy tym zauważyć, że tylko koło 30\% środków, jakie na działalność badawczą pozyskują uczelnie, pochodziło w 2014 roku z dotacji statutowej. Pozostałe dwa najistotniejsze źródła to przede wszystkim Narodowe Centrum Nauki (18\%) oraz Narodowe Centrum Badań i Rozwoju (z udziałem około 16,6\%) (GUS, 2015a, s. 190-191).

Tabela 2. Nakłady na działalność B+R w skali kraju i w zakresie przeznaczonym dla szkół wyższych w latach 2006-2014

\begin{tabular}{lcc}
\hline & $\begin{array}{c}\text { Nakłady wewnętrzne na B+R } \\
\text { w relacji do PKB [w \%] }\end{array}$ & $\begin{array}{c}\text { Przychody z działalności badaw- } \\
\text { czej szkół wyższych [w tys. zł] }\end{array}$ \\
\hline 2004 & 0,56 & 1366326 \\
\hline 2005 & 0,57 & 1436407 \\
\hline 2006 & 0,55 & 1533043 \\
\hline 2007 & 0,56 & 1932861 \\
\hline 2008 & 0,60 & 2092365 \\
\hline 2010 & 0,67 & 2330519 \\
\hline 2011 & 0,72 & 2693475 \\
\hline 2012 & 0,75 & 2865378 \\
\hline 2013 & 0,89 & 2864237 \\
\hline
\end{tabular}

Źródło: Obliczenia własne na podstawie danych GUS.

Trzeci analizowany obszar obejmuje publikacje autorów z polską afiliacją w bazie WoS. Odnosząc się do dostępnych danych, należy wskazać na duży ich przyrost (dwukrotnie więcej w 2014 roku niż w 2004 roku), największy - w zakresie sztuki i nauk humanistycznych, choć w liczbach bezwzględnych jest to wzrost z niecałych 100 tekstów do 660 rocznie. Nieodmiennie dominują nauki ścisłe, stanowiąc ponad 95\% publikacji polskich (współ)autorów w zasobach bazy referencyjnej. 
Tabela 3. Liczba tekstów autorów z polską afiliacją w Web of Science (wg roku publikacji) wg dziedzin nauki w latach 2014-2014

\begin{tabular}{|c|c|c|c|c|c|c|c|}
\hline & \multirow{2}{*}{$\begin{array}{l}\text { Artykuły } \\
\text { w WoS }\end{array}$} & \multicolumn{3}{|c|}{$\begin{array}{l}\text { Liczba tekstów wg dziedzin } \\
\text { nauki }\end{array}$} & \multicolumn{3}{|c|}{$\begin{array}{l}\text { Struktura tekstów wg dziedzin } \\
\text { nauki }\end{array}$} \\
\hline & & $\begin{array}{l}\text { nauki } \\
\text { społeczne }\end{array}$ & $\begin{array}{l}\text { nauki } \\
\text { technicz- } \\
\text { ne i przy- } \\
\text { rodnicze }\end{array}$ & $\begin{array}{l}\text { sztuka } \\
\text { i nauki } \\
\text { humani- } \\
\text { styczne }\end{array}$ & $\begin{array}{l}\text { nauki } \\
\text { społeczne }\end{array}$ & $\begin{array}{l}\text { nauki } \\
\text { technicz- } \\
\text { ne i przy- } \\
\text { rodnicze }\end{array}$ & $\begin{array}{l}\text { sztuka } \\
\text { i nauki } \\
\text { humani- } \\
\text { styczne }\end{array}$ \\
\hline 2004 & 36179 & 690 & 35391 & 98 & 1,91 & 97,82 & 0,27 \\
\hline 2005 & 37204 & 828 & 36258 & 118 & 2,23 & 97,46 & 0,32 \\
\hline 2006 & 40091 & 940 & 39016 & 135 & 2,34 & 97,32 & 0,34 \\
\hline 2007 & 42081 & 977 & 40858 & 246 & 2,32 & 97,09 & 0,58 \\
\hline 2008 & 44864 & 1362 & 43194 & 308 & 3,04 & 96,28 & 0,69 \\
\hline 2009 & 45783 & 1330 & 44091 & 362 & 2,91 & 96,30 & 0,79 \\
\hline 2010 & 55333 & 1658 & 53200 & 475 & 3,00 & 96,15 & 0,86 \\
\hline 2011 & 57594 & 1897 & 55268 & 429 & 3,29 & 95,96 & 0,74 \\
\hline 2012 & 63033 & 2270 & 60348 & 415 & 3,60 & 95,74 & 0,66 \\
\hline 2013 & 68864 & 2589 & 65780 & 495 & 3,76 & 95,52 & 0,72 \\
\hline 2014 & 72317 & 2767 & 68961 & 589 & 3,83 & 95,36 & 0,81 \\
\hline 2015 & 71703 & 2207 & 68832 & 664 & 3,08 & 96,00 & 0,93 \\
\hline $\begin{array}{c}\text { przyrost } \\
2004= \\
100 \%\end{array}$ & 198,2 & 319,9 & 194,5 & 677,6 & & & \\
\hline
\end{tabular}

Źródło: Obliczenia własne na podstawie danych WoS.

Znając ogólny obraz zmian w zakresie finansowania działalności naukowej, liczby pracowników ją podejmujących (w roli nauczycieli akademickich i pracowników B+R w sektorze szkolnictwa wyższego) oraz liczby artykułów autorów z polską afiliacją w bazie WoS, można zastanowić się, jakie wzajemne powiązania między tymi wartościami mogą zachodzić. Ponieważ prestiżowe publikacje są powszechnie przyjętym miernikiem jakości nauki, to właśnie ich liczba będzie stanowiła zmienną zależną w przeprowadzonych analizach korelacyjnych. We wszystkich analizowanych obszarach trend zmian w okresie 2004 (2006)-2014 jest analogiczny, ważna jest jednak również kwestia, czy można wskazać ich powiązanie na poziomie statystycznym.

Analiza relacji liczby pracowników nauki, tj. nauczycieli akademickich i pracowników B+R w sektorze szkolnictwa wyższego, ujawnia bardzo słabe wzajemne powiązania. Współczynniki korelacji liniowej Pearsona okazują się 
słabe, przy powiązaniu liczby artykułów w bazie referencyjnej z liczbą nauczycieli akademickich $\mathrm{Rxy}=0,26$, przy uwzględnieniu liczby pracowników B+R w sektorze szkolnictwa wyższego $R x y=0,07$, zaś stosunkowo najwyższą wartość osiąga przy uwzględnieniu liczby EPC Rxy=0,36.

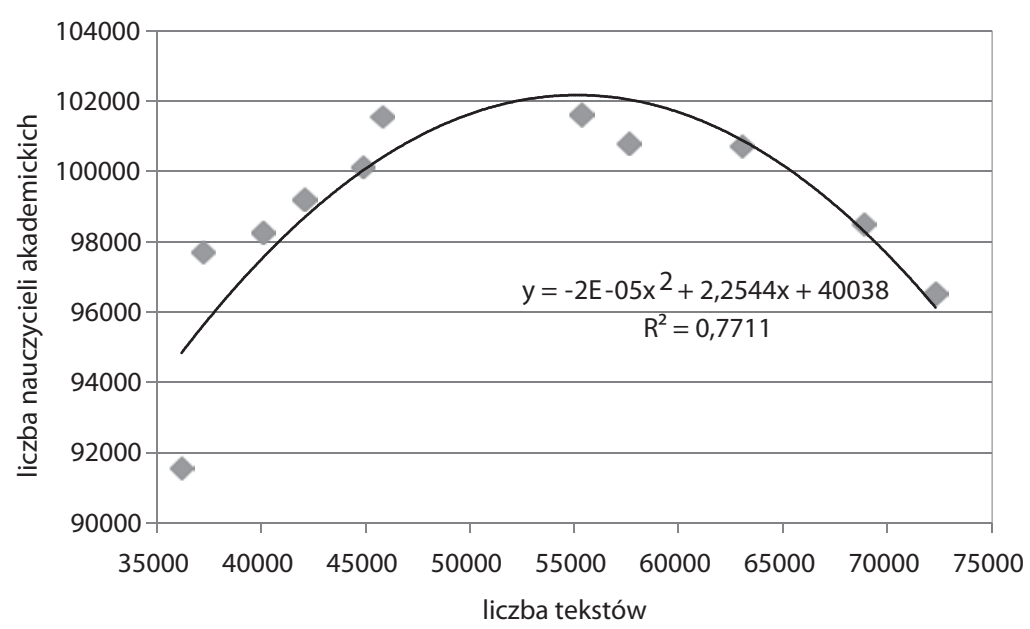

Rysunek 1. Model regresji wielomianowej dla liczby nauczycieli akademickich i liczby artykułów polskich autorów w Web of Science w latach 2004-2014 Źródło: Opracowanie własne.

Także analiza regresji relacji liczby artykułów polskich autorów w bazie referencyjnej do liczby nauczycieli akademickich wskazuje na niskie dopasowanie modelu linowego $(\mathrm{R} 2=0,0675)$ i znacznie lepsze dopasowanie ukazanego wyżej modelu wielomianowego. W odniesieniu do liczby pracowników $\mathrm{B}+\mathrm{R}$ z sektora szkół wyższych ich relacja do liczby artykułów w obrębie żadnego typowego modelu regresji nie osiąga dobrego dopasowania (dla modelu linowego, wielomianowego czy potęgowego wskaźniki dopasowania są niższe niż 0,01). Natomiast wykorzystanie przeliczenia na pełne etaty działalności $B+R$ daje nieco lepsze, choć nadal słabe dopasowania (dla modelu linowego $\mathrm{R} 2=0,1318$, dla modelu wielomianowego R2=0,1754).

Można zatem sądzić, że samo odniesienie liczby pracowników, niezależnie od przyjętego sposobu ich liczenia, do liczby odnotowanych w bazie artykułów nie oddaje dobrze trendu. Przyczyn może być wiele, najistotniejszą wydaje się długotrwałość i prawdopodobnie odmienna długość cyklu obu procesów, tj. zmian osobowych na uczelniach i publikowania. Presję publikowania odczuwają przede wszystkim pracownicy młodzi, walczący o awanse naukowe, przedłużenia eta- 
tów czy o granty. Jednocześnie zmiany w składzie osobowym uczelni, związane z wspieraniem zatrudnienia właśnie takich pracowników, są powolne i jest to raczej poszukiwanie szansy na nowe etaty z grantów (przeważnie nie z dofinansowania dydaktyki) czy zastępowanie pracowników odchodzących niż radykalne zmiany w składzie osobowym.

Drugie analizowane powiązanie dotyczy nakładów przeznaczonych na $\mathrm{B}+\mathrm{R}$ i będących ich owocem prestiżowych publikacji. Fundusze wpływające do szkół wyższych w ramach finansowania działalności badawczej, podobnie jak ogólnie wydatki na działalność badawczo-rozwojową, w ostatecznym rozrachunku powinny przekładać się na działalność publikacyjną - to ona jest bowiem miarą i głównym wskaźnikiem „produktu” w grantach wszelkiego poziomu.

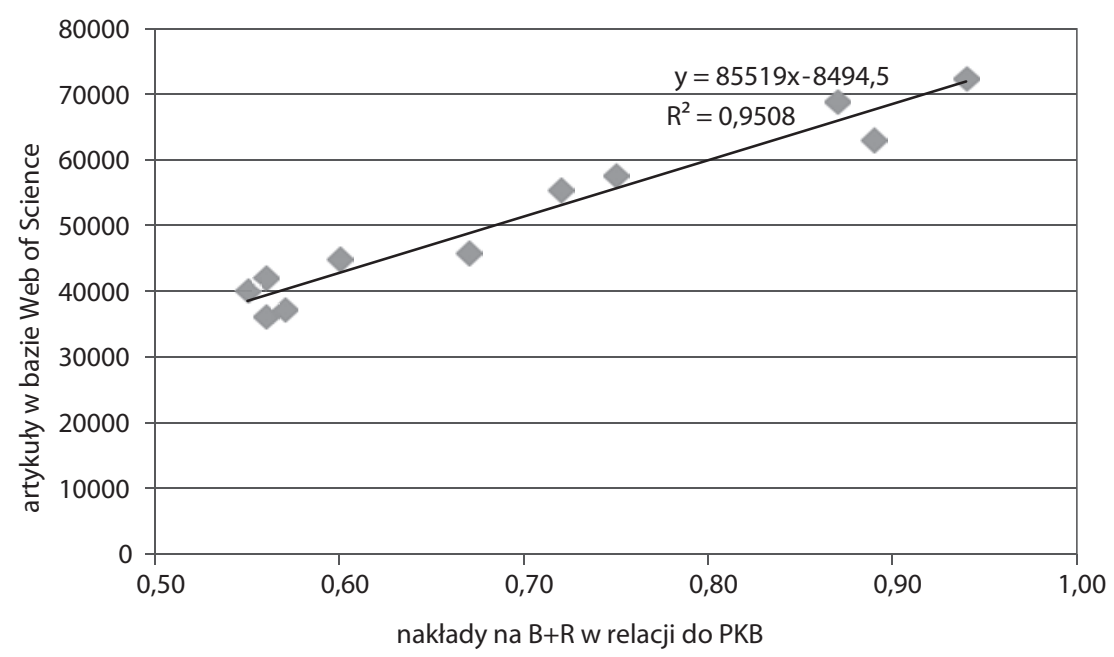

Rysunek 2. Model regresji liniowej dla wysokości nakładów na B+R (w relacji do PKB) i liczby artykułów polskich autorów w Web of Science

Źródło: Opracowanie własne.

W efekcie zdecydowanie klarowniejszy obraz daje analiza relacji nakładów na B+R i liczby artykułów polskich autorach w bazie Web of Science - dopasowanie modelu linowego okazuje się bardzo wysokie $(\mathrm{R} 2=0,95)$, co potwierdza też wysoki współczynnik korelacji liniowej Pearsona Rxy=0,975.

Podobny obraz można otrzymać, analizując wydatki kierowane do szkół wyższych z różnych źródeł, a przeznaczone na działalność badawczą. Sytuację tę obrazuje wyraźny trend, chociaż dopasowanie linii regresji jest niższe - dla modelu liniowego wynosi 0,8856, zaś dla wielomianowego R2=0,9299. 


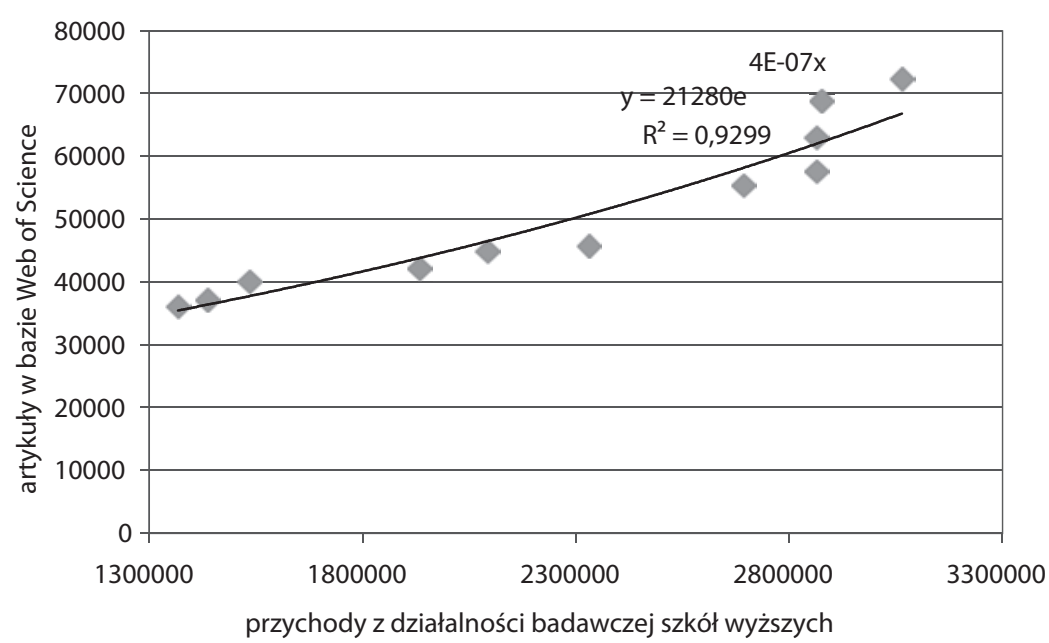

Rysunek 3. Model regresji wielomianowej dla wysokości nakładów na działalność badawczą szkół wyższych i liczby artykułów polskich autorów w Web of Science Źródło: Opracowanie własne.

Wyraźnie zatem publikacje idą w parze w większym stopniu ze środkami finansowymi przeznaczonymi na realizację badań naukowych, niż związane są z liczbą pracowników nauki - czy to wykazywanymi jako nauczyciele akademiccy czy też jako pracownicy prowadzący działalność B+R w sektorze szkolnictwa wyższego (zob. także Jeran, Piechowiak-Lamparska, 2015). W istocie nie jest to konstatacja zaskakująca - z jednej strony na prowadzenie badań niezbędne są środki finansowe, niezależnie od tego, czy są to badania podstawowe, czy stosowane i niezależnie od dyscypliny. Nie są one wydatkowane tylko na ściśle rozumianą realizację badań, ale także na prowadzenie szeroko rozumianego życia naukowego - wyjazdy konferencyjne, zakup literatury czy chociażby wsparcie w profesjonalnym przygotowaniu tekstów do publikacji. Z drugiej zaś w większości ośrodków naukowych, a szczególnie w szkołach wyższych, prowadzenie badań naukowych jest tylko jednym z zadań pracowników, a stopień zaangażowania w nie jest zróżnicowany (co ujawniają i potwierdzają wszelkiego rodzaju rankingi wydziałowe i co jest uwzględniane w wyznaczaniu współczynników parametrycznej oceny jednostek) (zob. Todorovsky, 1997). 


\section{WNIOSKI: GROŹBA UKRYTA MIĘDZY WIERSZAMI}

Dużo wyższa dynamika przyrostu liczby publikacji z nauk społecznych i humanistycznych niż zakresu nauk ścisłych (technicznych i przyrodniczych) może wskazywać na - z jednej strony - „oswojenie” reguł gry i wymogów publikowania w liczących się, światowych czasopismach, z drugiej zaś - na pojawienie się okoliczności i kompetencji umożliwiających takie publikowanie. Jak bowiem wiadomo - jedno to wola, a drugie to możliwości. Można mieć nadzieję, że rosnąca świadomość jednostek naukowych (m.in. związana z koniecznością utrzymywania wysokiego poziomu aktywności naukowej jako jednego z najbardziej efektywnych czynników wpływających na utrzymanie wysokiej oceny parametrycznej jednostek naukowych) i samych pracowników nauki przełoży się zarówno na wolę, jak i na możliwości. Pojawiają się bowiem coraz powszechniej, tak w grantach zewnętrznych, jak i w sposobach wydatkowania środków statutowych, rozwiązania służące wspieraniu publikacji wyników prac badawczych w możliwie najbardziej prestiżowy oraz widoczny w świecie sposób (wsparcie dla profesjonalnych tłumaczeń, proofreadingu, wnoszenia opłat za publikację).

Nadal otwarte pozostaje pytanie, czy wzrostowi liczby publikacji towarzyszy wzrost ich jakości - miarą tego byłaby analiza recepcji tekstów, a więc ich cytowań. Wydaje się, że brak wystarczająco kompletnych baz publikacji (zarówno światowych, jak i krajowych) nadal uniemożliwia rzetelne przeprowadzenie takich badań. Podejmowane próby, choć oparte najczęściej na mniej kontrolowanych źródłach jak chociażby Google Scholar, dają interesujące wyniki (zob. Jeran, Piechowiak-Lamparska, 2015; Dobbins, 2011; Eyre-Walker, Stoletzki, 2013; Śleszyński, 2013).

I wreszcie kwestie finansowe, w przypadku przedstawionych analiz związane z nakładami na $\mathrm{B}+\mathrm{R}$ i na działalność badawczą w szkolnictwie wyższym. Działalność $\mathrm{B}+\mathrm{R}$ postrzegana jest przede wszystkim jako sfera wdrożeń, komercjalizacji tego, co wypracowała nauka, ale w kontekście uwzględnianych typów badań w pełni obejmuje także badania podstawowe. Należy podkreślić, że na szczególną uwagę (być może przede wszystkim decydentów) zasługuje jednoznaczna, silna i pozytywna korelacja poziomu wydatków na działalność badawczą i rozwojową z liczbą publikacji odnotowanych w WoS. Uzyskany wynik z bardzo wysokim dopasowaniem modelu linowego $(\mathrm{R} 2=0,89)$ wskazuje, że - nawet jeśli nie poprzez proste mechanizmy - to jednak dokonuje się przełożenie nakładów na badania na obecność polskich naukowców w światowym obiegu nauki. Tym bardziej że tak wyraźnej korelacji nie wykazuje chociażby związek pomiędzy liczbą nauczycieli 
akademickich a liczbą publikacji polskich autorów w Web of Science (tu dopasowany był model wielomianowy, z niższym wskaźnikiem dopasowania R2=0,7711).

Czym zatem jest ukryta pomiędzy wierszami groźba - finansuj lub giń? Wydaje się, że rekomendacja dotycząca dalszego rozwoju polskiej nauki jest oczywista: aby zwiększyć prestiż polskiej nauki, konieczne jest zwiększenie finansowania z zakresu B+R. Zwiększenie finansowania badań naukowych będzie skutkowało także wyższą jakością edukacji (w szkołach wyższych będą zatrudniani najlepsi wykładowcy), wyższym poziomem badań naukowych (także większą ilością wdrożeń oraz lepszą współpracą z otoczeniem gospodarczym), a także dodatnio wpłynie na rozwój społeczny. Działania wspierające politykę publikacyjną w konsekwencji zwiększą obecność polskich naukowców w światowym dyskursie, ale także zwiększą ich atrakcyjność i udział w międzynarodowych zespołach badawczych. Jednak trzeba pamiętać, że nie polityka publikacyjna wspierająca polskie publikacje w czasopismach indeksowanych w WoS powinna być celem samym w sobie, lecz wspieranie realizacji dobrych badań (każdego rodzaju - od podstawowych po wdrożeniowe, w każdej dyscyplinie i dziedzinie wiedzy) - dobre badania oznaczają bowiem dobre wyniki, a dopiero publikowanie ciekawych, na światowym poziomie wyników, jest sens wspierać. Problemem w Polsce jest jednak nadal to, że przy braku dobrej polityki publikacyjnej, robiąc dobre badania, często trudno z ich wynikami dotrzeć do prestiżowych czasopism.

Na koniec warto podkreślić, że niewątpliwie istotne jest rozważenie mechanizmów stojących za zidentyfikowaną na poziomie statystycznym korelacją między nakładami na B+R a obecnością publikacji polskich autorów w prestiżowych czasopismach. Można sądzić, że pośredniczy tu kilka zazębiających się procesów, m.in.:

- jakość i ilość prowadzonych badań naukowych (więcej i lepszych prac badawczych oznacza więcej wyników, które trafiają do opublikowania w prestiżowych czasopismach i wydawnictwach);

- efekt zachęty dla pracowników B+R związany z uzyskiwaniem wyższych wynagrodzeń za podstawową działalności i możliwa dzięki temu kondensacja ich aktywności w sferze badawczej;

- zawarte w mechanizmach finansowania elementy polityki publikacyjnej (jak finansowanie tłumaczeń, proofreadingu czy opłat wydawniczych);

- umożliwienie współpracy między ośrodkami krajowymi i w skali międzynarodowej. 


\section{Podziękowania}

Inspiracją dla przedstawionego tekstu były dyskusje na temat jakości polskiej nauki, jakie prowadziłyśmy z prof. Ryszardem Borowiczem zimą 2013/2014.

\section{Literatura:}

Academic Ranking of World Universities. Academic Ranking of World Universities methodology. Pobrane z: http://www.shanghairanking.com/ARWU-Methodology-2016.html.

Borowicz, R. (2000). Jeszcze o polskich uniwersytetach. Głos Uczelni, 11. Pobrane z: http://glos.umk.pl/2000/11/uni.html.

Brada, J.C., Bienkowski, W., Kuboniwa, M. (red.). (2015). International Perspectives on Financing Higher Education. Springer.

Dobbins, M. (2011). Higher Education Policies in Central and Eastern Europe: Convergence Towards a Common Model? New York: Palgrave Macmillan.

GUS. (2015a). Nauka i technika w 2014 r. Szczecin.

GUS. (2015b). Szkoły wyższe i ich finanse w 2014 r. Warszawa.

Kaiser, F., Maassen, P., Meek, L., van Vught, F., de Weert, E., Goedegebuure, L. (red.). (2014). Higher education policy: An international comparative perspective. Elsevier.

Keszei, E., Hausz, F., Fonyó, A., Kardon, B. (2015). Financing Research Universities in Post-communist EHEA Countries. W: E. Keszei i in. (red.), The European Higher Education Area (s. 169-184). Springer International Publishing.

Kwiek, M. (2016). Changing Public-Private Dynamics in Polish Higher Education. International Higher Education, 86, s. 18-20.

Phillips, C.R., Olson, J.E. (2015). Cost of Education: To what extent are the final cost objectives of universities subsidized? Review of Business, 36 (1), s. 113-129.

Rozporządzenie Ministra Nauki i Szkolnictwa Wyższego z dnia 12 grudnia 2016 r. w sprawie przyznawania kategorii naukowej jednostkom naukowym i uczelniom, w których zgodnie z ich statutami nie wyodrębniono podstawowych jednostek organizacyjnych.

Śleszyński, P. (2013). Cytowania i oddziaływanie polskich ośrodków geograficznych według Google Scholar. Przegląd Geograficzny, 85 (4), s. 599-627.

Tilak, J. (2015). Global trends in funding higher education. International Higher Education, 42, s. 5-6.

Todorovsky, D. (1997). On the working time budget of the university teacher. Scientometrics, 40 (1), s. 13-21.

Wilkin, J. (2009). Ekonomiczno-finansowe uwarunkowania rozwoju szkolnictwa wyższego w Polsce. W: R.Z. Morawski (oprac.). Polskie szkolnictwo wyższe. Stan, uwarunkowania i perspektywy (s. 79-131). Warszawa: Wydawnictwa Uniwersytetu Warszawskiego. 